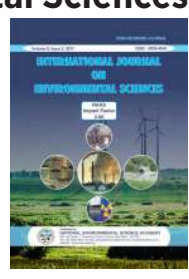

\title{
RAINWATER HARVESTING SYSTEM FOR TECHNO INDIA NJR INSTITUTE OF TECHNOLOGY ENGINEERING COLLEGE, UDAIPUR
}

\author{
Sangeeta Choudhary and Nishant Sharma \\ Civil Engineering Department \\ Techno India NJR Institute of Technology, Udaipur, Rajasthan
}

\section{Research Article}

Received: 11.08.2020

Revised: 28.08.2020

Accepted: 07.09.2020

\begin{abstract}
Rainwater harvesting is a process of saving rainwater through the roof and open floor along the proper slope. Rajasthan is facing crises of water due to less rainfall every year. It is required to develop systems for collecting the rainwater from existing structures for fulfills water demand throughout the year. In this project, a rainwater harvesting system has been made for Techno India NJR campus through visual inspection, total station, theodolite, and GIS survey. Visual inspection has been done. Rainwater can be harvested through roofs of the academic block, workshop, hostel building, and I3 lab of the college. Some more area which is occupied by tiles and road was also considered for rainwater harvesting. The total built-up area for collecting rainwater is $9138.824 \mathrm{~m} 2$. Average rainfall in Udaipur is $689 \mathrm{~mm} /$ year and $6296.138 \mathrm{~m} 3$ volume of water can be saving through recharge in bore well. Two points have been selected based on the survey of the campus.
\end{abstract}

Keywords: Rainwater harvesting, GIS survey, slopes, contours, campus, groundwater.

\section{INTRODUCTION}

There is very little fresh water on the earth's surface. Only $2 \%$ of water is useful for living beings and the remaining $98 \%$ is salted water and $87 \%$ is in ice form out of $2 \%$ of potable water (1) as represented by figure 1 . Rainfall is only medium to get fresh water in sufficient amount but rainfall distribution is very uneven throughout the year. It is required to store water during the rainy season before it merges into oceans. Rainwater harvesting is a very useful and easy method to save freshwater. It is necessary for today's urban scenario where the built-up area is increasing day by day and it reduces the absorption of water through the surface of the earth. Surface runoffs have increased after increasing the built-up area.

Rajasthan is a dry state and struggles with the scarcity of water (2). It is useful to plan the rainwater harvesting system at houses, institutes, and industrial levels to compensate for the loss of water during the rainy season (3). There are requirements for various types of surveys for designing a water harvesting system. Slopes and contours readings are required for identifying the correct points for recharge maximum rainwater at minimum cost. Rainwater harvesting systems should be constructed simultaneously during the construction of the buildings or houses (4).

This is the project of the Rainwater Harvesting System for the college campus. Auto level, theodolite, and the total station were used to determine slopes, contour, and the catchment area of campus respectively to design a rainwater storage system. The campus of Techno India NJR Institute of Technology is situated at $24.517588^{\circ} \mathrm{N}$ latitudes and $73.751580^{\circ} \mathrm{E}$ longitudes and is located in the Udaipur of Rajasthan. Thus water is the most natural resource being always in high demand by human beings and for gardening of campus(5).

*Corresponding author: sangeeta27apr@gmail.com 


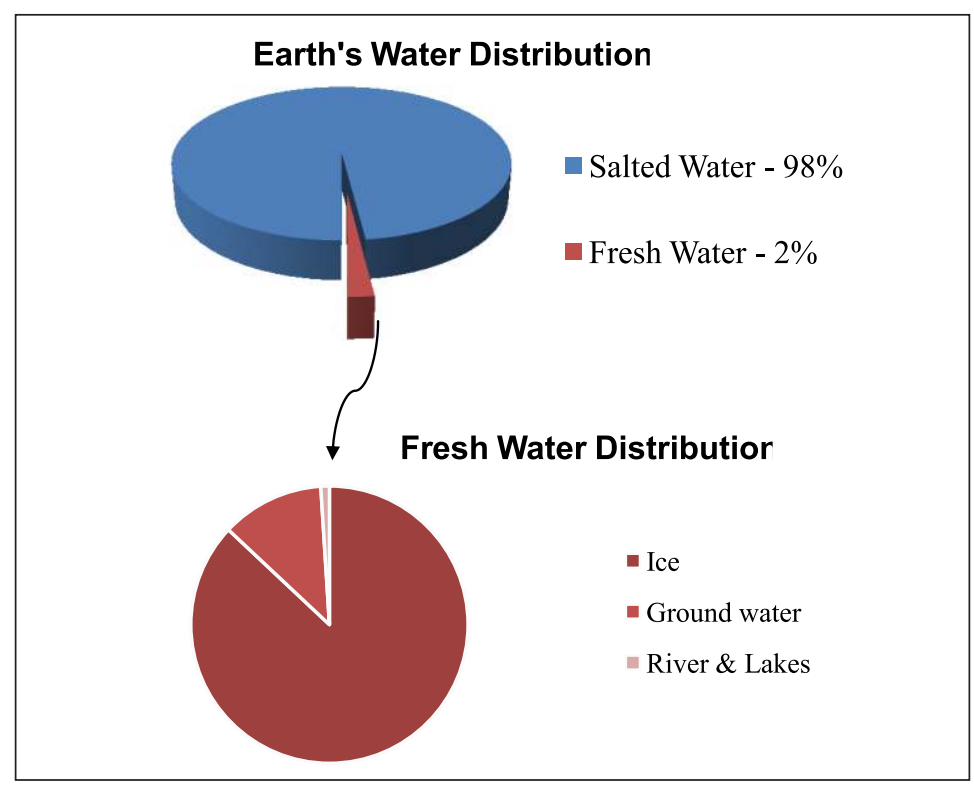

Figure 1: Earth's Water Distribution.

\section{Methodology}

Following four types of surveying techniques were used for the design of the Rainwater Harvesting System.

1. Geographic Information System Survey

2. Visual Inspection during the rainy season

3. Calculation of Catchment area through Total Station

4. Contouring and leveling of Campus

1. Geographic Information System Survey: Geographical Information System survey is considered as a preliminary survey that gives latitude, longitude, and area of campus. The location of the bore well is also mentioned in the Google map of the campus (6). This is a very useful survey for starting the detailed survey for calculating the area of campus, contour map, and profile leveling of the the proposed area for the rainwater harvesting system. Geographical Information Surveys play an important role in the planning of proper storage of rainwater. Figure 2 shows the study area of this project.

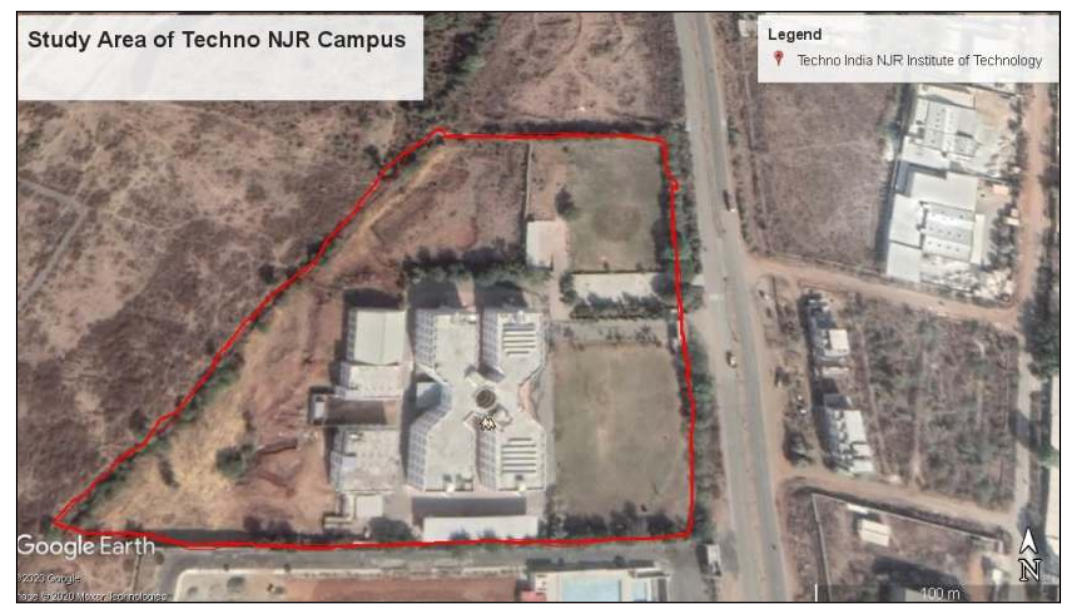

Figure 2: Study Area of Techno India NJR for Rainwater Harvesting System (7). 
2. Visual Inspection during the rainy season: This survey was conducted during the rainy season to identify the streams of water. It is a very important survey because boundaries are also affecting the streams of water. It is easy to make a decision precisely based on the flow direction of rainwater. This is a very important survey based on human intelligence. It increases the efficiency of the project. Maximum rainwater harvesting with minimum cost is the target of this project. There is a need to identify obstructions in slope gradients because it changes the flow of water. The instrumental survey is not enough for accuracy. Visual inspection is very easy for small areas and helps to make the right decision.
3. Calculation of Catchment area through Total Station: Whole catchment areas were calculated through the total station. The total station is a very useful equipment for calculating the exact area of campus which can be used as the catchment area for rainwater harvesting. It is an electronic device and makes a plan of the surveyed area. There are four buildings namely the academic block, workshop, hostel building, and I3 lab on the campus of this college. These buildings are surveyed for slope and catchment area. Other built-up areas like roads, the open area covered by tiles are also considered as a catchment area. Following are details of the catchment area after conducting a total station survey:

Table 1: Catchment Area.

\begin{tabular}{|l|l|l|}
\hline S.No. & Block Name & Ground Coverage (Square M.) \\
\hline 1 & Academic Block & 3377.01 \\
\hline 2 & WorkShop & 606.3 \\
\hline 3 & Hostel Building & 597.9064 \\
\hline 4 & I 3 lab & 275.394 \\
\hline 5 & Road & 2668.166 \\
\hline 6 & Area Covered by Tiles & 1613.306 \\
\hline & Total Area & $\mathbf{9 1 3 8 . 8 2 4 S q . ~} \mathbf{M}$ \\
\hline
\end{tabular}

4. Contouring of Campus through Auto Level: Contouring Slopes and levels of the study area are an important input for the design of the rainwater harvesting system (8). Profile leveling of the campus has been done through Autolevel as shown in figure 3 . Theodolite was used for a contour map of the campus. Figure 4 shows a contour map of the campus and it was concluded after contouring and profile leveling that there are two catchment areas and two recharge points for the collection of rainwater. One is on side of the front road and another is on the backside of the campus as mentioned in figure 5 .

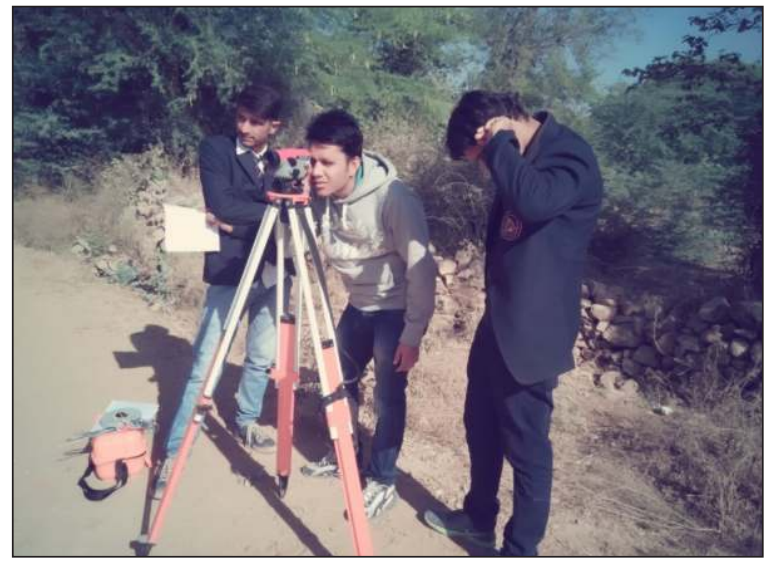

Figure 3 : Profile leveling through Auto level. 


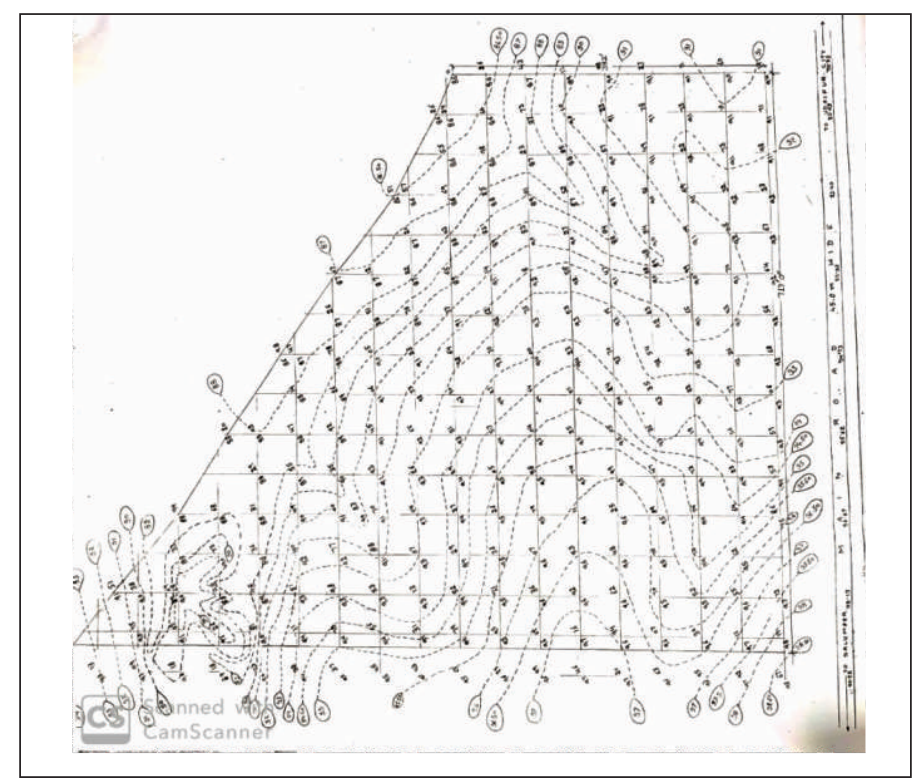

Figure 4: Contour Map of Campus created by college survey team.

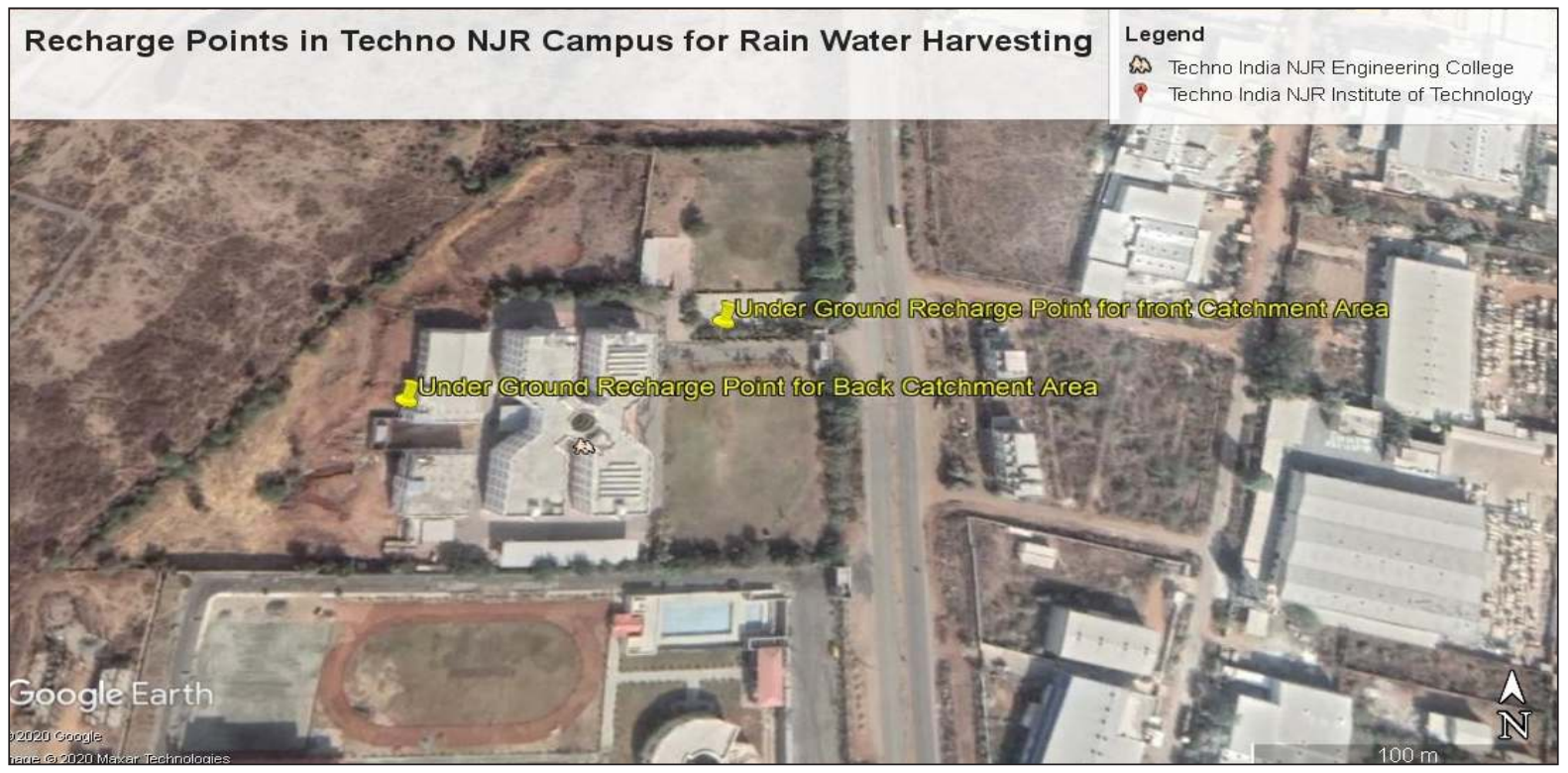

Figure 5: Recharge Points in Techno NJR Campus for Rain Water Harvesting System.

\section{RESULT AND DISCUSSION}

It is easy to plan and design the Rainwater Harvesting system after completing the survey work and other data collection. There is shown graph 1 on the rainfall data of Udaipur city and the average rainfall is around
$689 \mathrm{~mm} / \mathrm{year}$. The catchment area of the campus receives rainfall so the volume of rainwater can be calculated through the multiplication of average rainfall and catchment area of campus. 


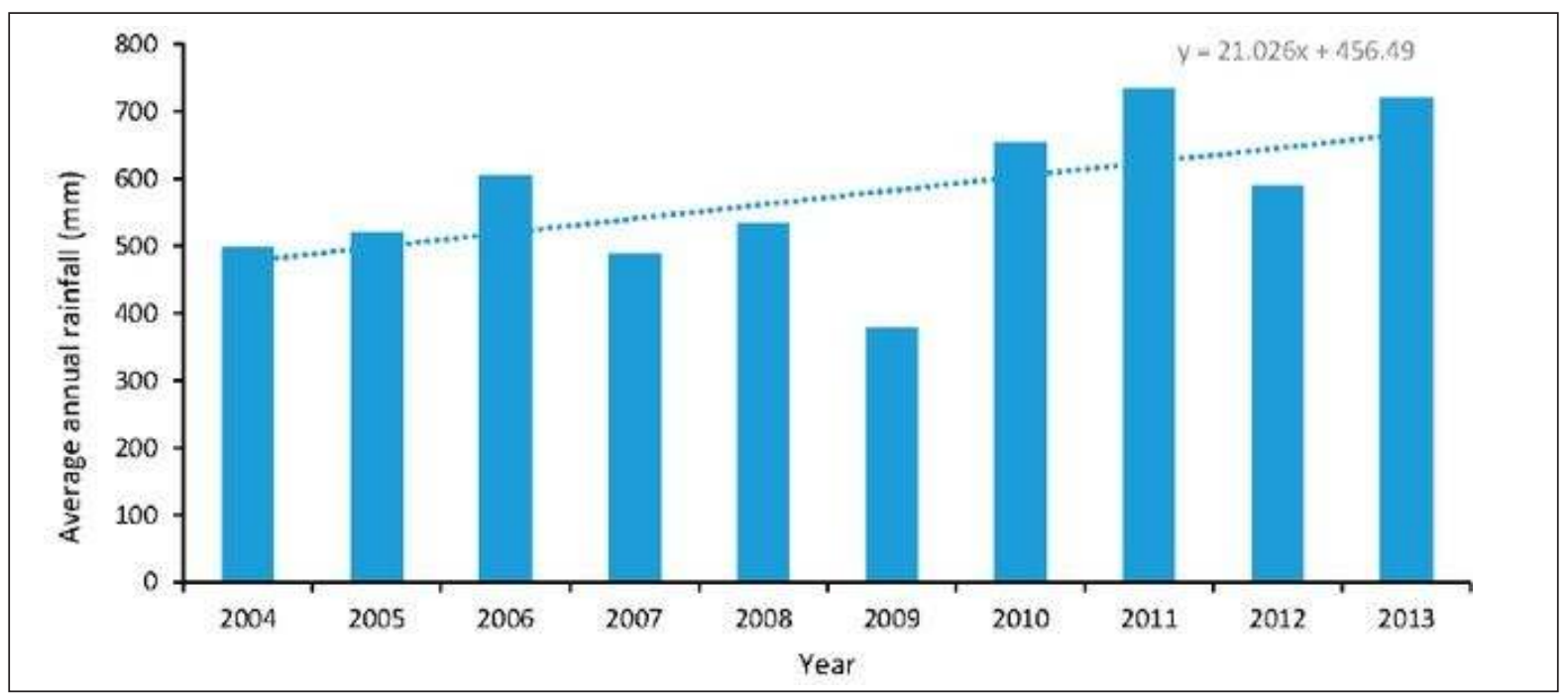

Graph. 1: Rainfall data of Udaipur City.

Following calculation has been adopted for rainwater to be stored. This includes the quantity of water and the cost of the rainwater harvesting system. Two recharge points are identifying for the construction of the bore well based on a visual inspection and profile leveling and contouring of the area. The design of the bore well is also suggested as shown in figure 6. There is a requirement for screens on bore well for preventing the large size impurities. It was decided that the depth of the bore well is 200 feet and the cost of digging one bore well is forty thousand.

\section{The calculation for the volume of rainwater to} be stored

- Average Rainfall in Udaipur $=689 \mathrm{~mm} /$ year

- Catchment Area of Campus = 9138.0824 Sq. m

- $\quad$ Volume of water $=0.689 \times 9138.0824$

$=6296.138 \mathrm{~m}^{3}$
- $1 \mathrm{~m}^{3}=1000$ litre

- $6296.138 \mathrm{~m}^{3}=6296.138 \times 1000$ litre = 6296138 litre

\section{Cost for Construction of Borewell}

- Depth of bore well = 200 feet

- Cost of 1bore well-digging = Rs 40000/-

- Cost of the pit above bore well $=$ Rs10000/-

- Total cost of 1 recharge point $=40000+$ $10000=$ Rs 50000/-

- $\quad$ Total number of recharge points $=2$

- Cost of 2 recharge point $=50000$ x2 = Rs $100000 /-$

- $\quad$ Cost of repairing of roofs of campus $=$ Rs $50000 /-$

- $\quad$ Total cost for RWH system = Rs $1,50,000 /-$

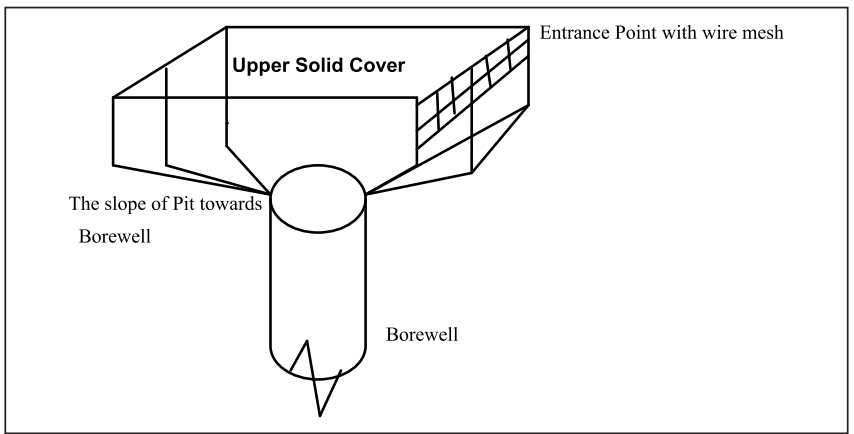

Fig. 6: Line diagram of bore well with Rectangular Pit. 


\section{CONCLUSION}

Rainwater harvesting system has been designed in Techno India NJR campus at very low cost through various surveys of the campus(9). This system makes a campus environment friendly. The natural flow of water has been surveyed through visual inspection during the rainy season. Recharge points were identified at the best location after completing the GIS, visual, auto level, and total station survey. The total station was used for calculating the total built-up area whereas the auto level was used to identify the slope and contour map of the campus. The average rainfall in the Udaipur district is $689 \mathrm{~mm}$ per year and the catchment area of the campus is $9138.0824 \mathrm{~m}^{2}$. So a total of 6296138 liters per year water can be saved in two bore wells.

\section{REFERENCES}

1. Mullen, Kimberly. The Groundwater Association. The Groundwater Association website. [Online] 2020. https://www.ngwa.org/ what-is-groundwater/ About-groundwater/ information-on-earths-water.

2. Drought and Scarcity in the Rajasthan Desert: Some Basic Issues. Jodha, N S. s.l. : JSTOR, 1969, Economic and Political Weekly, Vol. 4, pp. 699-703.

3. Rainwater Harvesting - A Campus Study. Abhijeet Keskar, Satish Taji, Rushikesh Ambhore, Sonali Potdar. July 2016. 3rd National
Conference on Sustainable Water Resource Development and Management.

4. Impact Assessment of Roof Top Water Harvesting Structure: A case Study from Wadi Area, Nagpur District, Maharastra. Anil M. Pophare, Abhay M. Varade, Nayusha Sathvane. January 2007.

5. Rooftop Rain Water Harvesting Potential: A case study of Dahivadi College Building and Campus in Man Tehsil of Satara District. Dr. Khilare C.J., Sachin Navnath Pawar, Namdas D.D., Vijay Gaikwad. January 2012. SWRDM.

6. Bell, Alan. Technical Guidance Surveying, Mapping, and Aerial Photography. s.l. : U.S. Department of the Interior Bureau of Reclamation Technical Service Center Denver, Colorado, 2016. Vol. September.

7. Techno India NJR Institute of technology. Udaipur, Rajasthan, India : Google Earth Image, 8 10, 2020.

8. Food and Agriculture Organization. Food and Agriculture Organization website. [Online]

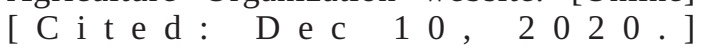
http://www.fao.org/fishery/static/FAO_Training /FAO_Training/General/x6707e/x6707e08.htm.

9. Rainwater Harvesting - A case study a Amba Township, Gandhinagar",. Anant D patel, Pratima Shah. 2015. National conference on "Transportation and water resource engineering". 